\section{Managing a Career in Place}

\author{
Diana D. Shonrock \\ Diana D. Shonrock is a Professor \\ Emeritus at lowa State University. \\ Correspondence concerning this column should \\ be addressed to Marianne Ryan, Dean of Libraries, \\ Loyola University Chicago, 1032 W. Sheridan Road, \\ Chicago, IL 60660; e-mail: mryan21@luc.edu.
}

For the past ten years, I have had the pleasure of serving as editor of RUSQ's Management column. In this space, I have enjoyed showcasing myriad perspectives on management broadly interpreted, articulated by an array of both aspiring and seasoned authors. As I prepared to hand off this responsibility after this issue, I realized that I have filled this role for longer than I ever spent at any one institution to this point in my career-which reminded me that an aspect of management I always wanted to present here is an entire career spent in one library. Managing a career in place, while not extinct, is a practice that waned over the years that our society became increasingly mobile and the notion of moving for opportunity took root. But in fact, a single library-if it's the right one-can offer the chance to try new things, satisfy a sense of possibility, and advance one professionally, without all the packing and relocating. In this interview, former RUSA President Diana Shonrock shares the story of how she happened into her start in librarianship —and realized a fulfilling, multi-faceted career-all in one place: Iowa State University (ISU) in Ames, Iowa._Editor

\section{MR: What took you to ISU?}

DS: I am originally from a small town in Iowa, and I headed there in the 1960s, as the first in my family to go to college, to purse a degree in Home Economics Education. When I began my studies at ISU, I knew I needed a job to survive since I was paying my own way. As a teenager, I had worked in both my high school and local public libraries to earn money for college, so getting a job at the university library proved a snap. I was excited to find out they paid a whopping one dollar per hour. WOW!!!

\section{MR: What kept you there?}

DS: Following graduation in 1969 with that degree in home ec-with emphasis in the areas of food science, textiles, and clothing-I accepted a position teaching for the ISU Library in the university's required library instruction course for undergraduate students known as Library $160 .{ }^{1}$ This position was supposed to be a two-year side trip while my husband completed his degree in urban planning, after which we planned to move to Chicago where he had grown up. We thought we could both find work in our fields there. Needless to say it didn't happen that way; as HUD money dried up and demand for urban planners fell, Ames offered new job opportunities for him. So we stayed in Iowa, and I continued to teach at the library. 
MR: What did you do during the summers, when you weren't teaching?

DS: I worked all over the library, in binding, archives, circulation, serials—you name it. It was all just a great learning experience for me, plus a chance to earn a little extra cash. During the first several years, I also spent summers taking courses (in addition to taking one per quarter throughout the school year) toward earning an MS degree in Family Environment-Housing.

MR: It sounds like you were still laying groundwork to work in the field of home economics. How did you find your way to a full-fledged career in libraries?

DS: You're correct. But about this time, the little seed was planted that while I loved teaching, I also loved librariesand maybe somehow I could combine the two. Finishing my MS coincided with the birth of my first child. Shortly after that, another series of occurrences affected the direction my career would go. Early in 1976, two colleagues and I were invited to speak about ISU's required instruction program at the Iowa Library Association/Association of College and Research Libraries (ILA/ACRL) Conference. Giving my first ILA/ACRL presentation opened me up to the wider world of librarianship. I subsequently became more active in both ILA and ILA/ACRL and did a variety of presentations related to library instruction for meetings and conferences. While my work at the library remained centered around instruction, in tandem it continued to evolve, affording me the chance to take on many different roles, thanks to an administration that was supportive and encouraging.

\section{MR: What happened next?}

DS: So many things! Following that initial ILA/ACRL presentation, members of our department began to write more about our unique instruction program, and we subsequently got more requests to speak. As technology began to affect everything, it was impacting library instruction. In 1978, in an effort to improve teaching Library 160, I worked with the media production unit on video tapes to vary our approach to conveying information to students in our classes. This included collaborating on writing, voicing, and evaluating a new video series for our course. In 1979, I gave a LOEX presentation on the ISU instruction program. About this same time, our department began to consider updating the manual we used as a text book and trying to use video tapes as a method of instruction.

In 1983, while still teaching Library 160, I received an invitation from the Central Iowa Region of the State Library of lowa to teach some short courses for public librarians, including one called "Survey of Public Services," which lead to an invitation in 1985 to serve on the State Library of Iowa's Continuing Education Certification Advisory Committee, the group responsible for advising the state library on certification and developing continuing education for public library personnel. The certification paths that we created are still being used to credential public librarians in Iowa.
As the department was rethinking our videos again in 1987, I collaborated on a research project and paper about using formative evaluation as a tool for improving instructional video tapes for Library $160 .^{2}$ This project led to an invitation to serve on the international Non-Theatrical Events Film Jury on campus that evaluated video films produced for educational use that were being considered for national and international awards. By 1989, ISU was invited to present a poster session about our now century-old instruction program as part of the ALA/ACRL 75th Anniversary celebration in Dallas. In 1990, I chaired the committee to completely re-envision and rewrite our instruction manual with the result being Access to Information, ${ }^{3}$ the first total rewrite of this manual in decades. Throughout my career, I was involved in forecasting and managing the integration of technology into the library and into instruction specifically.

In 1978, because of my subject background in home economics education, I was appointed liaison to the College of Home Economics—a college that never had a liaison from the library. It was yet another opportunity to grow and develop.

MR: Did you enjoy your work as a liaison-and was it a challenge to serve in that role without being a librarian? Over the years, this became one of the most rewarding areas of my work, but the relationship started slowly! The first thing that happened after my appointment was announced to the college was a phone call from a faculty member asking, "What's the best recipe for Boston baked beans?" At this juncture I knew that defining what "library liaison" meant would be an uphill battle and that it would require a lot of work to build mutual understanding and respect with the faculty. I found satisfaction in cultivating extremely strong relationships with administration, individual faculty members, and students. Little by little I began to work one-onone with faculty to teach research skills to their students and with department heads and deans to build stronger faculty researchers. Eventually, I was invited to teach or coteach units with various faculty collaborators-another way to apply the expertise I had developed through teaching Library 160. Several articles came from these collaborations, including one I coauthored about a four-week international housing project. ${ }^{4}$

Not being a librarian didn't deter my work at all. I had the background and experience to be successful and had already developed other strong relationships across campus. I know that many libraries still don't allow nonlibrarians to serve in liaison roles. I think that's a missed opportunity for both the libraries and the staff who could contribute in that way.

MR: Did you feel there was a turning point in your career? DS: In a sense, yes-it was in 1989. The ISU Library hired its first new dean in twenty-five years, ${ }^{5}$ and she encouraged me to pursue a graduate degree in Library and Information Science so I could move into management positions. That year, I began attending library school at the University of 
Iowa during evenings and summers. Thanks to the help from and the hospitality of many library friends and a supportive spouse, I completed my degree in 1992 while still working full-time and raising four children. After finishing library school—good to her promise — the dean appointed me Head of General Reference and Coordinator of Staff Training. This was yet another chance to teach, so I developed a new training program for reference staff. The dean also involved me in a nascent project related to text digitizing-a new world for me. This huge, \$500,000 grant project with Cornell University was coordinated by the United States Agricultural Information Network (USAIN) to digitize and preserve unique materials held by land grant universities and to select a company to do the digitizing. Work on this project included a presentation about the results for USAIN in 1990 and later involved collaboration with librarians at other project universities to develop a way to teach staff and constituents how to use this platform, cumbersome though it was. This initiative also evolved into another collaboration with Cornell to digitize a core collection of books and journals in home economics and related disciplines. Titles published between 1850 and 1950 were selected and ranked by teams of scholars for their historical significance. I served on one of the teams for the project that developed what is now called the HEARTH Project, ${ }^{6}$ opening new access to the world of electronic information.

\section{MR: What was a particularly meaningful opportunity you had at ISU?}

DS: I'd say there were two: one more library centric and the other connected to the broader campus community. The first came in 1992 with a phone call that changed 25 percent of my professional life for the remaining twenty years of my career. The call was from a retired army cook and cookbook collector from What Cheer, Iowa who told me he had about 12,000 cookbooks that he wanted to give to the library if I would take them. Apparently, another university in the state had turned him down. Of course, the decision as to whether or not the library should take and keep these books and ephemera was made with the head of collections and the head of archives, but the collection became my responsibility, one which eventually impacted a great many people and most of the departments throughout the library. The decision was made to accept the items with the proviso that we could dispense with any that were duplicates or didn't fit our collection scope. Suffice to say, a collection development nightmare had begun and a totally unique collection formed. Eventually I decided to keep mainly the books that were related to Iowa-the beginning of the Iowa Community Cookbook Collection that now numbers several thousand. Years of inventorying and policy discussions followed, in an effort to convince the administration that these books and the ephemera related to Iowa history were valuable enough to be cataloged and entered into OCLC. Over the course of the next twenty-five years, I refined the collection development policy for this material and made presentations for any and every group that would listen to me discuss my passion for the collection-another connection back to my home economics grounding. I also gradually became aware that there were similar efforts going on, mostly at land-grant universities, and I began to network with those other librarians and archivists. Access to this collection is still available online in archives. ${ }^{7}$

The other opportunity-or opportunities—came through my broader involvement across campus. I'll give just a few examples. Iowa State University was an early adopter of "Learning Communities," and in 1999, I was invited to serve on the initial steering committee. As part of my involvement on that group, I served on the Committee on Faculty Development that made a push for faculty teaching to carry more weight in the promotion and tenure process as "scholarship of teaching and learning." Later I served on the Committee on Curriculum where I cochaired a $\$ 20,000$ Miller Grant project with the freshman English coordinator, to merge freshman English and research methods. What resulted was a two-year test project developed and taught by the grant committee of English faculty and library faculty, which led to another LOEX presentation. ${ }^{8}$ Although the merger did not become permanent, Library 160 - a forerunner to what is known as information literacy in libraries today-continues to be required for graduation as it has been for over 120 years. And the new ISU president, the first woman in that role, has gone on record as supporting the continuation and strengthening of this required program. I'm pleased to have contributed to these initiatives and grateful to have been given a chance to do so.

\section{MR: It sounds like you had great support for ongoing professional development, too.}

DS: Absolutely. And that was something I realized I wanted; I knew what I learned would enhance the work I was doing in my day job. If I could be involved in ILA why not further involvement in other State of Iowa projects? At the suggestion of a colleague in 1987, I decided to join ALA. I immediately volunteered for a variety of library instruction committees and was appointed to two-the ACRL/Business Information Section (BIS)/Education for Instruction Committee and the Library Instruction Round Table (LIRT)/Research Committee-despite several colleagues telling me I wouldn't be selected because I didn't have an MLIS. Just some outcomes of these appointments included the opportunity to develop a survey of proficiencies needed by instruction librarians and eventually to coauthor an article for College and Research Libraries about the committee's survey results. ${ }^{9}$ That article ultimately led to being invited, in 1991, to cochair a BIS/ Association of Library and Information Science Education (ALISE) conference session, "Great Expectations! Library Education for Bibliographic Instruction: ALA/BIS/ALISE Forum," to bring together library school educators and instruction librarians to talk about common goals.

When I joined the LIRT Research Committee, it was discussing ways to put ideas for practical library instruction evaluation into a format that could be made available broadly to instruction librarians. As the discussions continued, it 
became clear that the committee might want to do a book for ALA Publications. I found myself as chair of the committee and serving as statistical advisor and editor for the book, Evaluating Library Instruction: Sample Questions, Forms, and Strategies for Practical Use. ${ }^{10}$ Writing and editing the book brought a three-month paid leave of absence from the university that I remember as a quiet time at home to finish a project, but which a couple of my children remember as a time I didn't hear them even though I was at home!

\section{MR: Sounds like you jumped in with both feet! Did that lead to even more service to the profession?}

DS: Oh, yes-and for the rest of my career! Soon after the cookbook collection was off the ground, I increased my involvement in ALA which included opportunities for leadership roles. In 1996, I was elected secretary of LIRT for three years. In 2001, I was elected chair-elect of ALA's Reference and User Services/Management of Operations and User Services Section (RUSA/MOUSS). It was during that threeyear span that I was responsible for guiding the reorganization of MOUSS, a section for reference managers, to ALA/ RUSA/Reference Services Section (RSS), thus broadening the membership of that section of RUSA to include all reference librarians. In 2005, I was elected president-elect of RUSA and served as president of the division from 2006-2007. Each of these positions allowed me to spread my wings and work with an ever-broadening group of people who influenced my thinking and broadened my world view.

Also in 2006, ALA's Allied Professional Association (APA) formed a task force to create a certification program for non-MLIS library staff. The ALA/APA Library Support Staff Certification (LSSC) Committee was designed to allow library staff to learn and master library background and information skills; it also was to be a mechanism to certify this knowledge as one might move from job to job and library to library. The committee worked with APA for three years before rolling out the program in 2010. It is being used by ALA/APA to this day.

\section{MR: Is there anything you found particularly challenging over the course of your career?}

DS: Every career has ongoing challenges, as I'm sure you know. But to cite one in particular, it was faculty status for librarians. I know that many librarians hate the idea of promotion and tenure in the university system; for me it was both a challenge and an opportunity. ISU was always a university where librarians earned promotion along with all university faculty. As I continued to have chances to take on new roles and expand my repertoire, I finally earned promotion to full professor based on the same qualifications as all ISU faculty. It took a while-thirty-nine years in my case—but I was proud of what I'd accomplished. In the years preceding, I served on a number of promotion and tenure committees within the library and across the university that worked to promote the importance of the scholarship of teaching.
As an aside, faculty status for ISU librarians ended in 2012 , then they began being appointed in the Professional $\&$ Scientific classification.

\section{MR: All told, how long were you at ISU?}

DS: More than forty-two years! Sometimes it seems like it was forever; other times it feels like it went by in the blink of an eye. And technically, it's even longer since I have emeritus faculty status. That means I can continue to be part of the ISU community.

\section{MR: Do you have advice or insights for anyone consider- ing a career in one place?}

DS: Remember that having a career all in a single library doesn't mean having only one job. Although I continued to teach Library 160 throughout my career, I also found a variety of new avenues to challenge my need for more. I was able to pursue my interests and continually learn new things in my library, on the campus, and at state and national levels in the profession-and to do it in a place where I understood the environment, knew the culture, and had long-term relationships that helped me thrive. ${ }^{11}$ Those elements are important in a career.

Why do some careers shape themselves as they do? Some seem driven while others seem to drive themselves? I don't know the answer, but I do know that I have no complaints about how my career unfolded. I believe that making strategic moves internally can be every bit as effective a way to climb the ladder as jumping ship and moving on-providing you share the values of the institution. Beyond that, the important thing is to seek growth opportunities rather than just coast along. Any position should be on a continuum of learning/sharing/moving forward. I never lost my love of teaching and learning and even today teach and take classes from the Osher Lifelong Learning Institute (OLLI). Next up is teaching a course on the Library of Congress.

Sadly, the emphasis on service in professional organizations seemed to be diminishing some as I was winding down my leadership involvement-in part perhaps because funding for professional development was being reduced in many libraries-though now it appears to be resurging as the importance of networking is rediscovered. I can't stress enough how important this can be for professional fulfillment-maybe more so for someone who spends a career in one place.

As I thought about this interview, I realized that it may be more unusual today to stay in one place than it was among my professional friends and colleagues across the country. They didn't all test my ability to keep my address book current-yes, that print thing I still have-and to figure out where everyone was. My daughter, however, who is under forty, has just started her fifth professional position since completing an MS in public policy. That said, recent data seems to suggest that people are actually changing jobs less frequently these days. ${ }^{12}$ Maybe my model will catch on again! 


\section{References and Notes}

1. Additional information on Library 160 is at https://instr.iastate .libguides.com/Libraryl60.

2. Diana D. Shonrock and Michael J. Albright, "Formative Evaluation as Tool for Improving Videotapes for Bibliographic Instruction," LOEX Conference, 1987.

3. Bibliographic Instruction Faculty, Iowa State University, Diana Shonrock, Coordinator, Access to Information: A Manual for Bibliographic Instruction at Iowa State University (Prospect Heights, IL: Waveland Press, 1990).

4. Diana D. Shonrock and Sue R. Crull, "Information Literacy and Cooperative Learning: A Global Housing Project," Public Services Quarterly 6, no. 1 (2010): 1-18.

5. Nancy Eaton served as Dean of Library Services at ISU from 1989-1997.

6. HEARTH Project, http://hearth.library.cornell.edu.

7. Iowa Community Cookbook Collection, http://historicexhibits lib.iastate.edu/iowacookbook/ and https://digitalcollections.lib iastate.edu/cookbook-collection.

8. Diana D. Shonrock, Daniel Coffey, and Jeanine Elise Aune, "Collaboration: Composition Instruction and Information Literacy in the Electronic Environment," LOEX Conference (Louisville, KY, 2005) 38: 131.

9. Diana Shonrock and Craig Mulder, "Instruction Librarians: Acquiring the Proficiencies Critical to their Work," College \& Research Libraries 54, no. 2 (March 1993): 137-49.

10. Diana D. Shonrock, Editor, Evaluating Library Instruction: Sample Questions, Forms and Strategies for Practical Use (Chicago: ALA Editions, 1996)

11. For an interesting perspective about the qualities important for long-term affiliation with an institution, see Erika Lynn, "Are You a Corporate Lifer? Females and the New Trend," Graduate Lincoln, October 8, 2015 and updated October 8, 2016, https:// www.huffingtonpost.com/erika-sales/are-you-a-corporate-lifer _b_8254598.html.

12. Jeffrey R. Young, "How Many Times Will People Change Jobs? The Myth of the Endlessly-Job-Hopping Millennial," EdSurge.com, July 20, 2017, https://www.edsurge.com/news 12017-07-20-how-many-times-will-people-change-jobs-the -myth-of-the-endlessly-job-hopping-millennial. 